Modern Asian Studies 4o, 3 (2006) pp. 545-548. (C) 2006 Cambridge University Press doi:10.1017/S0026749X0600206X Printed in the United Kingdom

\title{
Robert Hart and the Chinese Maritime Customs Service
}

\author{
HANS VAN DE VEN
}

University of Cambridge

\section{Preface}

In September 2003, academics from China, Europe and the USA gathered at Queen's University Belfast. They came first to attend an exhibition and then to present and discuss papers on the career in China of Robert Hart. ${ }^{1}$ Largely forgotten in Britain and even Northern Ireland, although not in the academic field of Chinese Studies, Robert Hart was born in County Armagh and studied at Queen's before travelling to Hong Kong in 1854 as a young recruit to the British Consular Service for China and Japan. He soon found himself despatched to the British consulate at Ningbo to study consular procedures and learn Chinese with the aid of a Chinese tutor and one of the Confucian classics, the Mencius. At this time, much of south China was engulfed by the Taiping Rebellion, which was inspired by Christianity.

In a step that would affect his own life and Chinese history, Hart accepted an invitation in 1859 to join what was still only an embryonic Chinese Maritime Customs Service. It was founded in 1854 when a local rebellion in Shanghai drove out the Qing official responsible for the collection of taxes on foreign trade. To be able to meet their treaty obligations and also to prevent merchants from countries without treaty relations with China to exploit the situation, the consuls of Britain, France, and the USA then established an office to assess duties on all foreign trade in accordance with the Tariff that had been

1 Funding for the conference was provided by the Chiang Ching-kuo Foundation, the Higher Education Funding Council for England, the Queen's University Belfast, and the Universities China Committee in London. It was organised by Drs Lan Li and Richard O'Leary of Queen's, assisted by Dr Robert Bickers of Bristol University and myself. Drs Lan Li, O'Leary, and Bickers have all provided valuable advice for and assistance with the compilation and editing of the articles published here.

oo26-749X/o6/\$7.50+\$0.10 
negotiated after the Opium War. Although its senior staff was made up of foreigners, it would always be subordinate to Qing authority.

Hart joined when this organization was extended from Shanghai to other Treaty Ports. Desperate for qualified staff, its chief of the time, Horatio Nelson Lay, scoured the trading houses and consular services on the China coast for recruits. Here was a unique opportunity for a young man with an eye for the main chance. Hart became acting Inspector General in 1861 and two years later was appointed full IG. Over the next decades, he built up the Service into one of the most important bureaucracies of the Chinese state. By the end of the nineteenth century, it accounted for one-fourth of revenue available to central Qing authorities. It had mapped, marked, and lit the China coast and China's major navigable rivers, including the Yangtze River. It policed the harbours of the more than forty Treaty Ports up and down the China coast. It also published a series of statistical and discursive reports on China's seaborne trade, accumulated data on climatic conditions, published regular Medical Reports and Notices to Mariners, and carried out diverse investigations in China's financial, economic, cultural, and social conditions. In addition to their Customs work proper, Hart, and other Customs Service employees, regularly played important diplomatic roles on behalf of the Qing. When Hart left China in 1907, the Service had grown into a large bureaucracy with thousands of employees.

The papers collected in this volume each offer distinct approaches to Robert Hart's history. We begin with Richard Horowitz's judicious reconstruction of Hart's rise to great power in China. Rather than describing him as someone who unselfishly aided China or facilitated British imperialism, as previous historians have done, Hart emerges in a more human way: as a man who was enormously competent, extremely shrewd, and, well ahead of his time, dubious about many aspects of British imperialism. He genuinely believed that British and Qing interests overlapped in many areas. But Horowitz also shows Hart as someone with overweening personal ambition who built the Service not into a modern rational bureaucracy run on a meritocratic basis, but as a quirky organization dominated by Hart personally and serving his own ambitions.

Richard O'Leary's essay examines Hart's Irish connections and shows that it is simplistic to see him as either Irish or British. Instead, O'Leary suggests that Hart held overlapping and multiple identities. Hart's background may have helped him construct, according to O'Leary, a bureaucracy that was international and may have made 
him sensitive to Chinese aspirations. He adds to Horowitz's efforts to humanize Hart by demonstrating that Hart was socially ambitious and sought to translate his success in China into higher status in Irish and in British society.

Andrea Bréard's contribution provides a detailed examination of the statistical work of the Customs Service. Robert Hart was the driving force behind it, and was made Honorary Fellow of the Royal Statistical Society for his efforts. This was a pioneering initiative. No modern state can work without statistics. All use them to organize, assess, classify, control, and mobilize the populations and resources of their countries. The article makes clear that Chinese officials were slow to make use of statistics or extend the collection of statistical information to other areas, perhaps in part because the Service was so successful in delivering new resources to central authorities. When the Qing did do so just before the 1911 Revolution, it turned to Japan rather than to the Customs Service for models, but the Customs Service continued to monopolize the production of statistics on China's trade.

My own article reconstructs Robert Hart's role during the Boxer Rebellion using fresh materials from a recently discovered file in the archives of the Customs Service held at the Second Historical Archives of China. I use the crisis in an attempt to reconstruct and explore the world of transnational elites of which Robert Hart was an important nodal point in China. Frank King's article follows on from mine, in that he discusses the history of the Boxer Indemnity, which Hart helped negotiate and for which Customs revenues stood guarantee. The size of the indemnity bore no proportion to the assessed financial damages and, King notes, may well have undermined the joint foreign aim of sustaining the Qing. He further illustrates that the demand to continue payments even after all claims had been settled could not but give rise to enormous nationalist resentments and international bickering, but he tempers this negative view of the Indemnity by reminding us that a good portion of it was rescinded while much of the rest was remitted to China for education purposes and capital projects.

Robert Bickers too deals with Robert Hart's impact after his death. His essay also uses the Customs Service archive in Nanjing to examine how Hart's successors used him to construct a beneficent image of the Customs Service. Bickers is highly critical of the efforts of a later IG, Frederick Maze, to impose his views. He brings out a linkage between post-1945 US China scholarship and the Customs Service's attempts to generate a positive image of itself. L.K. Little, an 
American who succeeded Maze as IG in 1943, provided a copy of Hart's correspondence to John Fairbank, the doyen of US China studies who himself had studied with H.B.Morse, a Statistical Secretary in the Customs Service, while at Oxford. Fairbank had concluded his study of the Sino-Western interactions with the founding of the Customs Service and argued that it was a cooperative Chinese-British institution that fostered modernity in an otherwise stagnant China.

Frank King's postscript 'Sealing the Mouth of Outrage' concludes the collection. King unravels Hart's choice of words when he decided to call the collection of articles he published during the Boxer Crises These from the Land of Sinim. It's an important reminder of the significance of religion and the complexity of human motives in a cynical age, and so makes a fitting conclusion to a collection of articles that have sought to re-assess and humanize a man who played a critical role at a time in Chinese history when, like now, it was most open to the outside.

Hans van de Ven

St Catharine's College

January 2005 